\title{
SOCIAL AND LIFE COURSE FACTORS AFFECTING THE DELAY IN SPEECH AND LANGUAGE DEVELOPMENT AMONG CHILDREN UNDER FIVE: MULTILEVEL ANALYSIS
}

\author{
Merlita Indriasih",2), Harsono Salimo3), Eti Poncorini Pamungkasari4) \\ 1)Pratama Amanda Clinic, Yogyakarta \\ 2)Masters Program in Public Health, Universitas Sebelas Maret \\ 3)Department of Pediatrics, Dr. Moewardi Hospital, Surakarta \\ 4)Faculty of Medicine, Universitas Sebelas Maret
}

\begin{abstract}
Background: Language and speech development in children under five serves an essential role in learning and building social relationship. Language and speech development delay may imply their personal and social life and academic achievement. This study aimed to examine social and life course factors affecting the delay in speech and language development among children under five.

Subjects and Method: This was a cross sectional study carried out at 25 integrated health posts (posyandu) in Sleman, Yogyakarta, from March to April 2019. A sample of 225 children under five was selected by fixed exposure sampling. The dependent variable was the delay in speech and language development. The independent variables were income, employment, nutritional status, birth weight, history of toxoplasma, rubella, Cytomegalovirus, and TORCH infection, history of infection, gadget use, language, frequency to posyandu visit, and "PAUD". Data on speech and language development was measured by Denver II. The other variables were collected by questionnaire. The data were analyzed by a multilevel logistic regression.

Results: High income ( $b=-1.49 ; 95 \% \mathrm{CI}=-2.83$ to $-0.15 ; \mathrm{p}=0.029)$, birth weight $(\geq 2,500 \mathrm{~g})(\mathrm{b}=-2.15 ; 95 \% \mathrm{CI}=-3.92$ to $-0.38 ; \mathrm{p}=0.017)$, mother working outside the house $(b=-1.29 ; 95 \% C I=-2.47$ to $-0.122 ; p=0.030)$, good nutritional status $(b=-1.50$; $95 \% \mathrm{CI}=-2.97$ to $-0.02 ; \mathrm{p}=0.049)$, mono language $(\mathrm{b}=-0.56 ; 95 \% \mathrm{CI}=-1.80$ to 0.68 ; $\mathrm{p}=0.378)$, regular posyandu visit $(\mathrm{b}=-1.34 ; 95 \% \mathrm{CI}=-2.58$ to $-0.11 ; \mathrm{p}=0.033)$, and "PAUD" ( $b=-1.55 ; 95 \% \mathrm{CI}=-2.82$ to $-0.2 ; \mathrm{p}=0.016)$ decreased the risk of delayed speech and language development. History of TORCH infection $(\mathrm{b}=1.77 ; 95 \% \mathrm{CI}=0.53$ to $3.02 ; \mathrm{p}=0.005)$, history of infection $(\mathrm{b}=0.89 ; 95 \% \mathrm{CI}=-0.32$ to $2.21 ; \mathrm{p}=0.149)$, number of children $>2(b=1.25 ; 95 \% \mathrm{CI}=0.40$ to $-2.46 ; \mathrm{p}=0.043)$, and gadget use $(\mathrm{b}=$ $1.33 ; 95 \% \mathrm{CI}=0.07$ to $2.59 ; \mathrm{p}=0.038$ ) increased the risk of delayed speech and language development. Posyandu had contextual effect on speech and language development with $(\mathrm{ICC}=9 \%)$.

Conclusion: High income, birth weight $(\geq 2,500 \mathrm{~g})$, mother working outside the house, good nutritional status, mono language, regular posyandu visit, and "PAUD" decrease the risk of delayed speech and language development. History of TORCH infection, history of infection, number of children $>2$, and gadget use increase the risk of delayed speech and language development. Posyandu has contextual effect on speech and language development.
\end{abstract}

Keywords: speech and language development, TORCH infection

\section{Correspondence:}

Merlita Indriasih. Masters Program in Public Health, Universitas Sebelas Maret. Jl. Ir. Sutami 36A Surakarta 57126, Central Java, Indonesia. Email: merlitaindriasih@gmail.com. Mobile: 085641097941. 